\title{
Do Estado positivo ao Estado regulador: causas e conseqüências de mudanças no modo de governança ${ }^{1}$
}

\section{Estratégia e estrutura}

Há mais de trinta anos, Alfred Chandler (1962: 16) propôs a tese de que "a estrutura acompanha a estratégia, e de que o tipo mais complexo de estrutura é o resultado da concatenação de várias estratégias básicas". Depois, ele levou a discussão teórica a um passo à frente ao fazer duas perguntas correlatas: (1) Se a estrutura realmente acompanha a estratégia, por que deveria haver atrasos no desenvolvimento da nova organização, necessária para atender às demandas administrativas da nova estratégia? (2) Por que a nova estratégia, que exigia uma mudança da estrutura, chegou primeiro?

A tese de Chandler teve profundo impacto sobre o estudo da moderna empresa industrial e da organização dos negócios de um modo geral. $\mathrm{O}$ mesmo não se verifica com relação ao estudo da política pública e da gestão pública, embora as questões levantadas por este eminente historiador econômico sejam tão relevantes para o setor público quanto o são para o setor privado. Tradicionalmente, as mudanças nas políticas públicas e nas estruturas da governança têm sido tratadas, na melhor das hipóteses, como processos tenuamente vinculados a serem analisados por subdisciplinas separadas, utilizando-se diferentes quadros conceituais e ferramentas analíticas. Essa separação empobreceu sobremaneira tanto a análise das políticas públicas quanto o estudo da administração pública. Progressos recentes na teoria positiva das instituições e na economia política das políticas públicas poderão, com o passar do tempo, levar a modelos gerais capazes de explicar tanto a inovação política quanto as correspondentes mudanças

Professor visitante de Ciências Políticas no Instituto Universitário Europeu, em Florença, Itália

Traduzido por René Loncan 
estruturais. Enquanto isso, no entanto, a transformação das políticas públicas e das estruturas da governança está ocorrendo num ritmo tal que o estudante de políticas públicas não pode aguardar o desenvolvimento de tais modelos antes de tentar entender o que está acontecendo.

Este artigo trata de mudanças estruturais significativas induzidas por uma "concatenação de várias estratégias básicas": a privatização, a liberalização e a desregulação (no sentido correto da reforma reguladora), a austeridade fiscal, a integração econômica e monetária e várias inovações em matéria de políticas ligadas ao paradigma da nova gestão pública. A despeito de sua heterogeneidade, essas novas estratégias concorrem para limitar o papel do Estado intervencionista ou positivo, especialmente ao restringir seu poder de tributar e de despender, ao mesmo tempo em que aumentam o poder normativo e, assim, o papel do Estado regulador. Embora a mudança do Estado positivo para o Estado regulador tenha recentemente atraído a atenção de vários estudiosos, especialmente nos Estados Unidos (Seidman e Gilmour, 1986), ainda nos faltam análises sistemáticas das conseqüências políticas, jurídicas e institucionais dessa mudança na governança. $\mathrm{O}$ artigo tenta proporcionar, mais que um levantamento exaustivo de seus muitos aspectos, um mapa ainda impreciso de um terreno em grande medida inexplorado.

\section{O declínio do Estado positivo}

As teorias político-econômicas modernas do Estado distinguem três tipos principais de intervenção pública na economia: redistribuição de renda, estabilização macroeconômica e regulação de mercados. A redistribuição de renda inclui todas as transferências de recursos de um grupo de indivíduos, regiões ou países, para um outro grupo, bem como a provisão de "bens de mérito" tais como educação primária, seguro social, ou certas formas de assistência à saúde que os governos obrigam os cidadãos a consumir.

A estabilização macroeconômica tenta atingir e manter níveis satisfatórios de crescimento econômico e de emprego. Seus instrumentos principais são a política fiscal e monetária juntamente com o mercado de trabalho e a política industrial. As políticas reguladoras têm como objetivo corrigir vários tipos de falhas de mercado: o poder de monopólio, as externalidades negativas, a informação incompleta, a provisão insuficiente de bens públicos.

Por detrás da noção de falha de mercado, há um teorema fundamental da economia do bem-estar, segundo o qual, em determinadas condições, os mercados competitivos levam a uma alocação ideal de recursos, 
segundo os termos de Pareto (Stiglitz, 1988). As falhas de mercado ocorrem quando uma ou mais condições da validade do teorema não são satisfeitas. Daí a regulação, se conseguir eliminar essas falhas a um custo razoável, poderá melhorar a eficiência do mercado, ou mesmo assegurar a viabilidade dos mercados, tais como a daqueles de serviços financeiros, onde a confiança, a transparência e a clareza de informações são de extrema importância.

Todos os Estados modernos se dedicam à redistribuição da renda, à gestão macroeconômica e à regulação de mercados, mas a importância relativa dessas funções varia de país para país e de um período histórico para outro. Assim, ao fim do período de reconstrução das economias nacionais minadas pela Segunda Guerra Mundial, a redistribuição e a gestão macroeconômica surgiram como prioridade política máxima da maioria dos governos da Europa ocidental. O mercado foi relegado ao papel de provisor de recursos para pagar pela generosidade governamental, e quaisquer provas de falhas de mercado eram consideradas suficientes para justificar a intervenção do Estado, muitas vezes sob a forma intrusa da alocação central de capitais e da nacionalização de setores-chave da economia. Realmente, a centralização e a política discricionária ilimitada chegaram a ser consideradas pré-requisitos da governança eficaz.

A importância atribuída às políticas de redistribuição e à gestão discricionária da demanda agregada revela-se nos rótulos "Estado do bem-estar", "Estado keynesiano" ou "Estado keynesiano do bem-estar", que se tornaram populares naquele período. No entanto, o consenso social-democrático sobre o papel beneficente do Estado positivo - como planejador, produtor direto de bens e serviços e como empregador de último recurso - começou a desmoronar-se nos anos 70. A combinação de crescente desemprego e de crescentes taxas de inflação não podia ser explicada dentro dos modelos da época, enquanto a despesa pública discricionária e as generosas políticas de bem-estar eram cada vez mais vistas como parte do problema do desempenho econômico insatisfatório.

Foi nessa época que a noção da falha governamental surgiu, com teóricos da escolha pública identificando vários tipos de falhas do setor público, exatamente como gerações anteriores de economistas haviam produzido uma lista sempre crescente de falhas de mercado. As políticas de nacionalização pareciam proporcionar uma evidência inquestionável do fracasso do Estado positivo. De um país a outro, empresas de propriedade estatal foram postas na berlinda por não conseguirem atingir seus objetivos sociais, bem como os econômicos, por sua falta de responsabilização e por sua tendência a serem capturadas por políticos e por sindicatos (Majone, 1996: 11-23). 
Não importa se essas críticas não são sempre justas ou empiricamente embasadas; o fato é que um número crescente de eleitores foi convencido por elas e se dispôs a apoiar um novo modelo de governança que incluísse a privatização de muitas partes do setor público, mais concorrência em toda a economia, maior ênfase na economia no lado da oferta e reformas de longo alcance no Estado do bem-estar. O fracasso da experiência socialista do presidente Mitterand em 1981/ 1982 reforçou a visão de que o redistributivismo keynesiano já não era possível em países que, como a França, estão estreitamente integrados nas economias européia e mundial.

Fica ainda mais claro, hoje em dia, que a globalização e, de forma mais imediata, a integração econômica e monetária dentro da União Européia estão promovendo a erosão da própria base do Estado positivo: seu poder de tributar (ou de tomar emprestado) e de gastar. Assim, o artigo 104c do Tratado de Maastricht conclama os Estados-membros a evitarem déficits governamentais excessivos e exige que a comissão "monitore o desenvolvimento da situação orçamentária e do estoque da dívida governamental dos Estados-membros, com vistas a identificar erros grosseiros". O parágrafo $11^{\circ}$ do mesmo artigo dá ao Conselho de Ministros da Economia e de Finanças a autoridade para exigir que os Estados-membros que têm déficit governamental excessivo "façam um depósito não gerador de juros, num montante apropriado ... até que o déficit excessivo tenha sido corrigido, na opinião do Conselho", e/ou impor multas.

Ademais, o fato de que somente variáveis monetárias tenham sido utilizadas para estabelecer os critérios de convergência, que os membros da unificação devem satisfazer, indica que não houve uma verdadeira troca entre estabilidade de preços, de um lado, e crescimento e emprego, de outro (Tsoukalis, 1993: 219). Em suma, o ativismo do Estado positivo é crescentemente limitado por uma variedade de fatores internacionais, europeus e domésticos. A natureza e os aspectos temporais das primeiras reações em matéria de políticas àquelas limitações variaram muito de país para país, mas agora todos os governos europeus, inclusive aqueles das antigas economias centralmente planificadas, parecem estar adotando, grosso modo, o mesmo modelo novo de governança.

\section{O crescimento do Estado regulador}

O novo modelo, que começou a surgir no fim dos anos 70 , inclui a privatização, a liberalização, a reforma dos esquemas de bem-estar e também a desregulação. Realmente, junto com a privatização, a desregulação é geralmente considerada como uma de suas características 
mais distintivas. Paradoxalmente, o mesmo período assistiu a um crescimento expressivo da formulação de políticas reguladoras tanto em nível nacional quanto europeu (ver abaixo). No entanto, o paradoxo é mais aparente do que real. A verdade é que, neste período, métodos tradicionais de regulação e de controle estavam ruindo sob a pressão de potentes forças tecnológicas, econômicas e ideológicas, e foram desmantelados ou radicalmente transformados. Isto é freqüentemente chamado "desregulação", mas o termo é enganador. O que se observa na prática não é um desmantelamento de toda a regulação governamental — uma volta a uma situação de laissez-faire que na realidade nunca existiu na Europa - mas, em vez disso, uma combinação de desregulação e nova regulação, possivelmente em um nível diferente de governança.

Assim, a privatização dos serviços públicos é normalmente seguida de regulação de preços, enquanto que empresas recentemente privatizadas perdem sua imunidade preexistente em relação às leis de concorrência nacional e européia. Realmente, o poder dos operadores titulares (e antigos monopolistas) para expulsar rivais em potencial do mercado é tão grande em indústrias desse tipo, que os governos têm de intervir a fim de limitá-lo. Neste caso, como em outros, os concorrentes devem sua existência às limitações reguladoras impostas sobre seus maiores rivais.

A desregulação também pode significar regulação menos rígida ou restritiva. Por exemplo, a rationale para alguma forma de intervenção governamental tem sido raramente questionada em áreas crescentemente importantes da regulação social - meio-ambiente, saúde, segurança, proteção ao consumidor. A questão aqui não é, falando em termos estritos, desregulação, mas, antes, como se atingir alguns objetivos reguladores através de métodos menos pesados. Assim, a substituição de normas ambientais por cobranças pela poluição não elimina a regulação ambiental, mas apenas introduz diferentes instrumentos de política, presumivelmente mais eficazes.

Longe de constituir um desvio da tendência geral no sentido de um Estado mais enxuto e eficiente, a importância crescente da regulação na Europa é melhor entendida como uma conseqüência direta dos mesmos processos que contribuíram para o declínio do Estado positivo. Isto pode ser mostrado, considerando-se três desses processos: a privatização, a europeização da formulação de políticas e o crescimento do governo indireto ou terceirização, a serem discutidos na próxima seção.

Para entender a relação entre a privatização e a regulação (mais precisamente a regulação legal administrada por agências ou comissões independentes), deve-se ter em mente que a propriedade pública tem sido, historicamente, o modo principal de regulação econômica na Europa. Embora a existência de empresas estatais remonte ao século XVII, seu uso se tornou disseminado somente no século XIX, com o desenvolvimento dos 
serviços públicos: o gás, a eletricidade, a água, as ferrovias, o telégrafo e, mais tarde, o telefone. Esses setores, ou partes deles, são monopólios naturais, produzem bens necessários, e eram amiúde considerados estrategicamente importantes. Daí supunha-se que a propriedade estatal daria ao Estado o poder para impor uma estrutura planejada à economia, e ao mesmo tempo proteger o interesse público contra interesses privados poderosos.

No entanto, a experiência viria mostrar que a propriedade e o controle estatais não podem ser considerados a mesma coisa. Realmente, o problema de se impor controle público efetivo sobre as grandes empresas nacionalizadas mostrou-se tão impraticável que o objetivo principal pelo qual haviam sido ostensivamente criadas - regular a economia em função do interesse público — foi quase esquecido (Majone, 1996: 11-15).

$\mathrm{O}$ fracasso da regulação através da propriedade estatal explica a mudança para um modo alternativo de controle, pelo qual os serviços públicos e outros setores, considerados importantes ao interesse público, são deixados em mãos privadas, mas sujeitos a regras desenvolvidas e aplicadas por agências especializadas. Essas entidades normalmente são criadas por estatuto, como autoridades administrativas independentes, no sentido de que lhes é permitido operar fora da linha de controle hierárquico pelos ministérios do governo central. Assim, o nexo causal entre a privatização e a regulação legal proporciona uma importante explicação, ainda que parcial, para o crescimento do Estado regulador.

Uma segunda variável explicativa é a europeização da formulação de políticas, que se traduz na crescente interdependência das políticas domésticas e supranacionais dentro da Comunidade Européia/União Européia (CE/UE). Este processo complexo ainda é mal entendido, mas para os fins deste artigo é suficiente chamar a atenção para dois aspectos bastante livres de controvérsia: a posição central da regulação na formulação européia de políticas, de um lado, e o impacto das políticas da CE e seus desdobramentos reguladores sobre os Estados-membros, de outro.

A importância da normatividade na CE é mostrada, em primeiro lugar, pelo crescimento quase exponencial, durante as três últimas décadas, do número de diretrizes e regulamentos produzidos pelas autoridades de Bruxelas a cada ano. Como resultado, até 1991, a CE estava introduzindo no corpo do direito francês mais regras do que as próprias autoridades nacionais: estima-se que hoje em dia somente $20 \%$ a $25 \%$ das normas legais aplicáveis na França sejam promulgadas pelo governo nacional sem qualquer consulta prévia a Bruxelas (Conseil d'Etat, 1993). No entanto, à medida que o programa de mercado único ultrapassou seu apogeu, o crescimento das diretrizes da CE/UE diminuiu seu ritmo e algumas foram retiradas em nome da subsidiariedade. 
A regulação européia cresceu não apenas do ponto de vista quantitativo, mas também qualitativo. Especialmente a partir da Lei Européia Única, que introduziu a votação de maioria qualificada para uma série de importantes áreas de política, as regras européias frequientemente têm sido mais inovadoras que aquelas de todos ou da maioria dos países da UE (Majone, 1996: 74-78). Também é importante notar que a expansão das competências da CE/UE permaneceu, em grande medida, limitada à regulação econômica e social. Por exemplo, embora a regulação ambiental da CE hoje inclua mais de 200 peças de legislação (de modo que, em muitos Estados-membros, o corpo do direito ambiental de origem comunitária é maior do que o de origem puramente doméstica), as competências européias na área da política social permanecem bastante limitadas. Voltaremos às razões para essa expansão seletiva das competências numa seção posterior.

É claro, de qualquer maneira, que o crescimento notável das regulações européias não poderia deixar de ter um impacto significativo sobre o desenvolvimento de políticas e instituições reguladoras em nível nacional. A política de concorrência fornece o melhor exemplo deste impacto. Quando o Tratado de Roma foi assinado, somente a Alemanha, entre os membros fundadores, tinha uma lei anti-truste moderna e um corpo regulador forte, o Escritório Federal de Cartéis, para implementá-la. Quarenta anos mais tarde, todos os membros da União Européia têm leis de concorrência, que se assemelham substancialmente à lei européia, e autoridades de concorrência que estão estreitamente vinculadas à Direção de Concorrência (DG IV) da Comissão. Realmente, a DG IV recentemente deu início a um projeto de descentralização com o objetivo de ter, a longo prazo, um estatuto comunitário da concorrência, aplicado em toda a UE por uma rede que inclua as autoridades nacionais de concorrência, os tribunais nacionais e a própria DG IV.

Uma estratégia de parceria coordenada entre reguladores nacionais e europeus teria sido impensável mesmo há dez anos. Atualmente é possível, porque surgiu espontaneamente entre os Estados-membros um alto nível de harmonização de leis nacionais de concorrência, e porque os reguladores nacionais da concorrência estão tornando-se mais profissionais e crescentemente ciosos de sua independência para com seus próprios governos (Laudati, 1996).

Embora a evolução jurídica e institucional não esteja tão avançada em outras áreas de formulação de políticas reguladoras, pode-se notar uma tendência geral no sentido da harmonização dos enfoques reguladores e uma estreita cooperação entre reguladores nacionais e seus contrapartes no nível europeu. $\mathrm{O}$ que é ainda mais significativo para o crescimento do Estado regulador - a delegação de poderes importantes no nível europeu não diminuiu, mas na verdade aumentou a importância das políticas 
e instituições reguladoras em nível nacional. Este paradoxo aparente é de fácil explicação. No sistema de formulação de políticas criado pelo Tratado de Roma, a implementação da maioria das regras da CE é de responsabilidade dos Estados-membros, que muitas vezes têm de criar novas entidades, ou pelo menos expandir organizações existentes para esse fim. Ademais, em muitos casos, a lei comunitária cria novas responsabilidades reguladoras para os governos nacionais. Por exemplo: a maioria dos regulamentos ambientais e de proteção ao consumidor nos países da Europa meridional foram desenvolvidos a fim de implementar diretrizes da CE. Mesmo no Reino Unido, o presidente da Comissão de Saúde e Segurança recentemente observou que a $\mathrm{CE}$ agora deve ser considerada como o motor principal dos regulamentos de saúde e segurança que afetam o Reino Unido, não apenas em matéria de segurança do trabalho, mas em assuntos envolvendo riscos importantes e na maioria dos assuntos ambientais (Baldwin, 1996).

Resumindo, a fim de tomar parte ativa na formulação de todas essas novas regras em Bruxelas, e então implementá-las internamente, os Estados-membros foram forçados a desenvolver capacidades reguladoras numa escala sem precedentes. Assim, o desenvolvimento da CE como Estado regulador influenciou fortemente uma evolução paralela nos Estados-membros.

\section{A face interna do Estado regulador}

A mudança do governo direto para o indireto ou por aproximação (Seidman e Gilmour, 1986) é a terceira causa importante do crescimento do Estado regulador, mais precisamente, do crescimento do que Hood e James (1996) chamaram a face interna do Estado regulador. Aspectos familiares dessa evolução incluem: a descentralização e a regionalização administrativas; a divisão de entidades antigamente monolíticas em unidades com uma única finalidade e com orçamentos próprios; a delegação de responsabilidade pela prestação de serviços a organizações privadas, lucrativas ou sem fins lucrativos, e a entidades não-ministeriais que operam fora do quadro normal do Poder Executivo; licitações e outros arranjos contratuais, ou quase-contratuais, competitivos, através dos quais os poderes para elaborar orçamentos e tomar decisões são delegados a compradores que, em nome de seu grupo de clientes, compram serviços dos prestadores que oferecem o melhor value for money.

Um exemplo importante é o programa britânico "Próximos Passos", cuja maior realização foi a quebra do serviço público unificado. Três anos depois do início do programa, mais de $50 \%$ dos funcionários públicos 
haviam passado de departamentos ministeriais para agências, que podem ou não vir a ser privatizadas, e, ao fim de 1994, cerca de $62 \%$ dos funcionários públicos o haviam feito. Como assinala Dowding, embora tenha havido agências anteriormente, a diferença principal entre essas e as agências do programa "Próximos Passos" é o acordo-quadro negociado entre a agência e o departamento central. Esse acordo pode ser visto como um plano empresarial que estabelece objetivos atuais e futuros, arranjos financeiros, condições básicas de emprego e os procedimentos revisados, através dos quais o departamento (ministério) central monitorará a agência (Dowding, 1995: 75).

O governo indireto envolve não apenas uma estrutura de responsabilidades, mas também novas formas de controle e de responsabilização. Se os formuladores de política desejam controlar ou influenciar as agências e outras organizações que operam com certa autonomia, devem fazê-lo através de arranjos contratuais e por meio de regras e regulamentos: "o governo através da regulação é o concomitante inevitável do governo por aproximação" (Seidman e Gilmour 1986: 128).

Num sistema de governo indireto, a gestão, cada vez mais, tende a ser identificada mais com a regulação de terceiros, que proporcionam os bens e serviços, do que com a responsabilidade e a responsabilização pela prestação de serviços. Como assinalam Hood e Scott, a terceirização, a delegação a entidades não-ministeriais e a contratualização (na qual compradores e prestadores operam através de contratos formais ou, pelo menos, através de quase-contratos, mesmo ambos sendo organizações públicas) levaram entidades internas de regulação a ter uma ação mais penetrante. Assim, os Comissários do Serviço Público, originalmente criados para organizar o recrutamento "por mérito" de funcionários públicos, têm constantemente aberto mão do lado operacional do recrutamento, e seu papel principal, nos termos de uma "Ordem de Conselho" de 1995, tornou-se o de um regulador que estabelece normas e verificações de controle de qualidade (Hood e Scott, 1996: 13-14). Também nos termos do programa "Próximos Passos", a regulamentação da prestação do serviço público está surgindo como uma das funções-chave dos ministérios centrais.

A Comunidade Européia proporciona um exemplo interessante de governança indireta na área da padronização técnica. A partir do novo enfoque delineado no White Paper de 1985 sobre a conformação do mercado interno (Comissão das Comunidades Européias, 1985), as diretrizes européias agora se restringem a estabelecer as exigências essenciais que os produtos devem satisfazer. Essas exigências essenciais compreendem, sobretudo, a proteção da saúde, da segurança, do meioambiente e do consumidor. A especificação de normas pormenorizadas 
é delegada a entidades normativas européias: Comité Européen de Normalisation (CEN), Comité Européen de Normalisation Electrotechnique (CENELEC), e European Telecomunications Standards Institute (ETSI). Essas são associações de direito privado das organizações de padronização dos Estados-membros.

As relações entre a Comissão da $\mathrm{CE}$ e as entidades de padronização européias são reguladas de forma contratual. Assim, os arranjos contratuais entre a Comissão e a CEN/CENELEC especificam que as propostas da Comissão para harmonização técnica devem referir-se explicitamente a normas estabelecidas por aquelas organizações. Também se espera que a Comissão apóie ativamente o uso de normas européias nos âmbitos doméstico e internacional. Por sua parte, a CEN e a CENELEC assumem a responsabilidade por assegurar que suas normas estarão de acordo com as exigências essenciais das diretrizes da CE. Em caso de dúvidas quanto à conformidade, o assunto é encaminhado a um comitê permanente, que é uma junta consultiva da Comissão. Além disso, as entidades de padronização garantem o direito de todas as partes interessadas (usuários da indústria, sindicatos, consumidores, agências estatais) participarem do processo de estabelecimento de normas, e, em especial, o direito da Comissão de ser convidada a todas as reuniões dos comitês técnicos. Em resumo, nos termos da nova abordagem, a Comissão abriu mão do lado operacional da harmonização técnica e, em vez disso, assumiu a responsabilidade pelo monitoramento da qualidade e da justiça do processo de criação de normas em nível europeu.

Antes de ir adiante, pode ser útil resumir-se a argumentação desenvolvida até agora. No espírito da tese de Chandler, identificamos uma "concatenação de várias estratégias básicas" conducente ao crescimento do Estado regulador em seu duplo papel de reguladora externo, ou de mercado, e de regulador interno. Discutiu-se três grupos de estratégias: a privatização, a liberalização e a reforma reguladora (desregulação); a adaptação das políticas e instituições domésticas para aprofundar a integração européia e a mudança para o governo indireto. Durante as duas últimas décadas, todos os governos da Europa ocidental adotaram essas estratégias, embora o tempo, a velocidade e a determinação de suas escolhas tenham variado muito de país para país. Daí as adaptações estruturais necessárias para atender às demandas políticas e administrativas das novas estratégias não são igualmente bem desenvolvidas na Europa inteira. A tendência geral, contudo, é razoavelmente clara, e é dessa tendência, mais do que de acontecimentos específicos de países, que trata a segunda parte do artigo (Quadro1). 
Quadro 1: Comparando dois modelos de governança

\begin{tabular}{|l|l|l|}
\hline \multicolumn{1}{|c|}{ Modelos } & \multicolumn{1}{|c|}{ Estado positivo } & \multicolumn{1}{c|}{ Estado regulador } \\
\hline Itens comparados & $\begin{array}{l}\text { Redistribuiçãos estabilização } \\
\text { macroeconômica. }\end{array}$ & Corrigir falhas de mercado. \\
\hline Instrumentos & $\begin{array}{l}\text { Tributação (ou tomar fundos } \\
\text { emprestados) e dispêndio. }\end{array}$ & Formulação de regras. \\
\hline $\begin{array}{l}\text { Arena principal de conflito } \\
\text { político }\end{array}$ & Alocações orçamentárias. & $\begin{array}{l}\text { Revisão e controle da } \\
\text { formulação de regras. }\end{array}$ \\
\hline $\begin{array}{l}\text { Instituições características } \\
\text { Parlamento, departamentos } \\
\text { ministeriais, empresas } \\
\text { nacionalizadas, serviços de } \\
\text { bem-estar social. }\end{array}$ & $\begin{array}{l}\text { Comissões parlamentares, } \\
\text { agências e comissões } \\
\text { independentes, tribunais. }\end{array}$ \\
\hline Atores-chave & $\begin{array}{l}\text { Partios políticos, funcionários } \\
\text { públicos, grupos corporativos. }\end{array}$ & $\begin{array}{l}\text { Movimentos em prol de } \\
\text { questões singulares, } \\
\text { reguladoras, peritos, juízes. }\end{array}$ \\
\hline Estilo de políticas & Discricionário. & Limitado por regras, legalista. \\
\hline Cultura de políticas & Corporativista. & Pluralista. \\
\hline Responsabilização política & Direta & Indireta \\
\hline
\end{tabular}

\section{Tributação e despesa $x$ criação de regras}

A maioria das diferenças estruturais entre o Estado positivo e o Estado regulador podem ser examinadas retrospectivamente, em última análise, em relação a uma distinção entre duas fontes de poder governamental: a tributação (ou tomar fundos emprestados) e a despesa, de um lado, e a criação de regras, de outro. Em termos concretos, esta é uma distinção entre políticas que exigem o dispêndio direto de recursos públicos e as políticas reguladoras. O ponto crucial é que as limitações orçamentárias têm impacto muito reduzido sobre a elaboração de regras, enquanto o tamanho de programas de despesa direta não-reguladores é determinado por dotações orçamentárias e, assim, pelo nível de receitas tributárias do governo.

O orçamento público é uma limitação leve que se impõe aos formuladores de regras, porque o custo real dos programas reguladores não é absorvido pelos reguladores, mas por aqueles que têm de obedecer à regulação. Nas palavras de Christopher De Muth (1984: 25), um antigo administrador em assuntos reguladores na Repartição de Gestão e Orçamento dos Estados Unidos da América:

"As cifras de orçamento e de receita são bons resumos do que está acontecendo nas políticas de bem-estar social, de defesa ou tributárias, e podem ser utilizadas para comunicar, de maneira 
eficiente, com o público em geral sobre o conflito dos grupos de interesse relativo, programa por programa, ... No mundo da regulação, todavia, onde o governo comanda, mas quase tudo ocorre na economia privada, geralmente nos faltam bons números agregados para descrever o que está sendo "tributado" e "dispendido" na busca da implementação das políticas públicas. Em vez disso temos listas, listas infindáveis de projetos que o governo gostaria que outros assumissem."

É impossível exagerar na significação dessa diferença estrutural entre as políticas reguladoras e aquelas que envolvem o dispêndio direto de recursos públicos. A distinção é especialmente importante no nível europeu, uma vez que não apenas os custos econômicos, mas também os custos políticos e administrativos da implementação das regras européias, são absorvidos, direta ou indiretamente, pelos Estados-membros. Realmente, as características estruturais da elaboração de políticas reguladoras explicam o viés regulador da elaboração das políticas comunitárias (Majone, 1996: 64-66).

Resumidamente, a explicação é a seguinte. A despeito do crescimento significativo em anos recentes, o orçamento da UE representa apenas 2,4\% de toda a despesa dos setores públicos dos Estados-membros e menos de $1,3 \%$ do produto interno bruto da União. Por comparação, entre $45 \%$ e $50 \%$ da riqueza produzida nos Estados-membros são gastos pelos governos nacionais e locais. O orçamento da UE não é apenas muito pequeno, mas também é rígido: mais de 50\% do total das dotações consistem de despesas obrigatórias. Esses recursos vão, em sua maioria, para a política agrícola comum e para um punhado de programas redistributivos. O que resta é insuficiente para sustentar iniciativas de grande escala em campos politicamente atraentes, como a política industrial, programas de bem-estar social e de criação de empregos, pesquisa ou inovação tecnológica. Em vista destas limitações, a única maneira pela qual a Comissão Européia pode aumentar a sua influência é expandindo o escopo de suas atividades de regulação: a elaboração de regras coloca muito poder nas mãos das autoridades de Bruxelas, a despeito das estritas limitações orçamentárias impostas pelos Estados-membros. Em outras palavras, uma vez que a CE não tem o poder independente de tributar e de dispender, ela poderia aumentar suas competências somente através do desenvolvimento de um tipo quase que puro de Estado regulador.

Modelos recentes do comportamento burocrático proporcionam outro exemplo da importância de se distinguir entre regulação e outros tipos de elaboração de políticas. Um dos mais conhecidos modelos de escolha pública da burocracia parte do pressuposto de que os funcionários tentam maximizar as dimensões dos orçamentos de suas agências. Segundo este 
modelo, a maximização de orçamento é possível porque os gestores das agências conhecem o custo verdadeiro de produção de um bom nível de serviços, enquanto que o Parlamento e outros órgãos supridores de fundos não dispõem desse tipo de informação (Niskanen, 1971). Conforme assinala Dunleavy (1991), no entanto, Niskanen desenvolveu seu modelo levando em conta agências que administravam programas de despesa direta. A maximização orçamentária pode ser uma hipótese plausível para esse tipo de agência, mas, pelas razões dadas acima, não o são para agências reguladoras. Realmente, as teorias econômicas da regulação não fazem qualquer uso da hipótese da maximização dos orçamentos ao modelar o comportamento dos reguladores. Segundo tais teorias, os reguladores maximizam sua utilidade, não através do ocultamento da função custo que consiste, em grande medida, de custos de pessoal, que o órgão financiador pode estimar com razoável exatidão - mas, antes, fornecendo benefícios reguladores a vários grupos de interesse (Majone, 1996: 31-34).

A ausência de uma limitação orçamentária geradora de obrigações para a elaboração de políticas reguladoras tem várias conseqüências importantes. Em primeiro lugar, nem o Parlamento nem o governo determinam sistematicamente o nível geral de atividade reguladora para um dado período. Em segundo, nenhuma repartição é responsável por estabelecer prioridades em matéria de regulação de todo o governo. Finalmente, embora os programas que envolvem despesa sejam regularmente objeto de auditoria, nenhum controle deste tipo é exercido sobre programas reguladores. Numa tentativa de corrigir esses problemas, alguns analistas da regulação aventaram a idéia de um "orçamento regulador" (Litan e Nordhaus, 1983). Neste contorno básico, esse orçamento seria estabelecido para cada agência, talvez começando-se com um orçamento total (nacional), e alocando-o entre as diferentes agências. Segundo as intenções de seus defensores, o orçamento regulador clarificaria os custos de oportunidade de adotar-se um regulamento e, assim, incentivar a eficiência em termos de custos. A consideração simultânea de todos os novos regulamentos também permitiria que seu impacto conjunto sobre setores específicos e sobre a economia, como um todo, fosse levado em conta.

A Repartição de Orçamento e Gestão (OMB) dos Estados Unidos aplicou a idéia em base experimental, aparentemente com bons resultados. O que é importante para nós, no entanto, não é o sucesso dessas ou de outras propostas para melhorar o processo regulatório, mas o que esse debate sugere: no Estado regulador, o contexto político muda da arena tradicional do processo orçamentário para uma nova arena onde a jurisdição sobre o exame e controle do processo regulatório proporciona a principal fonte de conflito. Segundo Seidman e Gilmour (1986: 129-131), Reagan foi o primeiro presidente dos Estados Unidos a perceber claramente o significado 
da regulação num governo que dependia crescentemente de agências que operavam fora do Poder Executivo normal; e entender que a revisão das regulações tomaria o lugar da revisão orçamentária tradicional, uma das principais ferramentas gerenciais disponíveis para o gestor de cada agência.

Daí a crescente importância da OMB, que se localiza no Escritório Executivo, como uma espécie de "Câmara de Compensação Reguladora". A Portaria $n^{\circ}$ 12.291, de 17 de fevereiro de 1981, determinou que deveria ser aplicado um teste de custo-benefício a todas as mais importantes regras e regulamentos, dando à $\mathrm{OMB}$ o poder de estabelecer os critérios para a determinação de quais regras e regulamentos eram "mais importantes". A mão da OMB foi reforçada ainda mais pela Portaria $\mathrm{n}^{\circ} 12.498$, de 4 de janeiro de 1985, que exige que cada agência se submeta a uma "visão geral de suas políticas reguladoras, metas e objetivos por ano de programa, bem como informações relativas a todas as ações reguladoras significativas da agência em fase de planejamento ou de implementação... conforme o diretor $(\mathrm{OMB})$ considere necessário desenvolver o programa regulador da administração" (Ibidem, 131).

O Congresso dos Estados Unidos se opôs fortemente, embora em última análise sem sucesso, a esse monitoramento centralizado do processo regulador. Seidman e Gilmour concluíram que, embora no passado a disputa entre o presidente e o Congresso pelo poder de dirigir as políticas públicas tenha centrado sobretudo em questões relativas a alocações orçamentárias e à estrutura do Poder Executivo, agora o principal conflito gira em torno do controle da normatividade.

Isto ocorre de maneira ainda mais intensa na União Européia, onde o contraste entre os Estados-membros e o Executivo da CE, em termos das alocações orçamentárias, empalidece em comparação com o conflito sobre o escopo, o nível e os métodos de criação de normas. $\mathrm{O}$ Tratado de Maastricht é apenas o mais recente estágio de uma luta constante pelo controle da regulação européia. Assim, embora a Lei Européia Única tenha ampliado consideravelmente os poderes reguladores da Comissão, o tratado freqüentemente exclui a harmonização das leis dos Estados-membros em novas áreas de competência comunitária. Muitas disposições novas dão a impressão de que seu objetivo primordial não é tanto legitimar o poder regulador da CE em alguns novos campos, mas, antes, assegurar que este poder não seja usado além de certos limites — uma impressão que é apenas reforçada pela inclusão do princípio da subsidiariedade no Tratado. Ademais, as declarações anexadas ao tratado sobre transparência e acesso à informação e sobre a avaliação em termos de custo-benefício de propostas da Comissão deveriam ser vistas como parte do mesmo esforço por monitorar, de maneira mais próxima, o processo regulador. 


\section{Da burocracia centralizada ao modelo de agências}

Entre as conseqüências estruturais mais óbvias da mudança para um modo regulador de governança, figura a ascensão de uma nova classe de agências especializadas e de comissões que operam autonomamente em relação ao governo central. A redistribuição de renda e a gestão macroeconômica exigem um alto nível de centralização na formulação de políticas e na administração. Daí um serviço público unificado, grandes empresas nacionalizadas e burocracias do bem-estar social expandidas serem instituições características do Estado positivo. As demandas administrativas do exercício da normatividade, todavia, são bastante diferentes. Essas demandas são melhor atendidas por organizações flexíveis e altamente especializadas que gozem de autonomia considerável no processo de tomada de decisões: as agências reguladoras independentes.

Os defensores do modelo de agências, por vezes, argumentam como se o modelo fosse incondicionalmente superior aos métodos tradicionais de elaborar e implementar políticas. Isto não é verdade, evidentemente. Por exemplo, as políticas redistributivas, ou políticas que tenham consequiências expressivas em termos de redistribuição, deveriam permanecer sob o controle direto dos dirigentes políticos. O modelo de agências só é aplicável em áreas limitadas, mas importantes, como as da regulação econômica e social e outras atividades administrativas em que conhecimentos e experiência específicos e reputação sejam a chave para maior eficácia.

Nessas áreas, as agências independentes gozam de duas vantagens significativas: conhecimentos e experiência específicos e a possibilidade de assumir comprometimentos dotados de credibilidade política. A fé na força dos conhecimentos e experiência específicos como motor da melhoria social - a especificidade técnica que nem legisladores nem tribunais nem generalistas burocráticos presumivelmente possuem sempre foi uma fonte importante de legitimidade para os reguladores, especialmente nos Estados Unidos. Segundo escritores da era New Deal, tais como Merle Fainsod quando jovem (1940: 313), as comissões reguladoras surgiram e se tornaram instrumentos importantes da governança precisamente porque o Congresso e os tribunais se revelaram incapazes de satisfazer ao "grande imperativo funcional" da especialização. As comissões independentes se "auto-elogiavam porque ofereciam a possibilidade de atingir a especialização e a experiência específicas no tratamento de problemas especiais, uma relativa liberdade com relação às exigências da política partidária em sua consideração dos assuntos e a sua celeridade no trato dos mesmos". James Landis (1996 [1938]: 23), um dos mais conhecidos estudiosos e especialista da regulação nos Estados Unidos, 
escreveu que "as demandas por conhecimentos e experiência específicos, por uma continuidade de preocupações, ..., levam naturalmente à criação de autoridades limitadas em sua esfera de ação para as novas tarefas que o governo deve empreender".

Certamente, os defensores das comissões independentes da época do New Deal, conforme diz Fainsod, sabiam que os conhecimentos e experiência específicos da burocracia reguladora não estão sempre livres de suspeitas. Ainda assim, eles justificavam a criação das comissões pela maior facilidade no recrutamento de peritos ou especialistas para uma agência independente do que para departamentos (ministérios) do Poder Executivo. Isso pode ser menos verdadeiro atualmente, quando os ministérios rotineiramente recrutam peritos de alto nível e podem contar com extensas redes de consultores. A verdadeira vantagem comparativa das agências independentes é a combinação de conhecimentos e experiência específicos com a "continuidade de preocupações" mencionada por Landis.

A continuidade de políticas é notoriamente difícil de se conseguir numa democracia, que é uma forma de governo pro tempore. O limite de tempo imposto pela necessidade de eleições com intervalos regulares é um constrangimento forte que se impõe ao uso arbitrário, por parte dos vencedores das disputas eleitorais, dos poderes com que investem os eleitores. No entanto, a segmentação do processo democrático, em períodos de tempo relativamente curtos, tem sérias conseqüências sempre que o problema enfrentado pela sociedade exigir soluções de longo prazo. Na expectativa da alternância, os políticos têm poucos incentivos para desenvolverem políticas cujo sucesso, se houver, virá depois da próxima eleição. Assim, é difícil para os dirigentes políticos se comprometerem com credibilidade e com estratégias de longo prazo. O problema do comprometimento é ainda mais agravado pelo fato de, no processo de tomada coletiva de decisões, haver muitas maiorias possíveis cujas preferências respectivas não necessitam de ser consistentes. Novamente, uma vez que os "direitos de propriedade política" são atenuados — uma legislatura não pode obrigar a sua subseqüente, e um governo não pode comprometer outro governo - as políticas públicas sempre são vulneráveis e renegadas, e conseqüentemente lhes falta credibilidade.

Uma solução importante para o problema do comprometimento consiste em delegar os poderes de elaboração de políticas a instituições, como os bancos centrais independentes e as agências reguladoras, ou mesmo a autoridades supranacionais, como a Comissão Européia. Seja em nível nacional ou supranacional, a lógica da delegação é sempre a mesma. Nas palavras de Gatsios e Seabright (1989: 46), "a delegação de poderes reguladores a alguma agência diferente do próprio governo é ... 
melhor entendida como um meio através do qual os governos podem comprometer-se com estratégias de regulação que não teriam credibilidade na ausência dessa delegação. É uma questão aberta, em qualquer caso específico, se o comprometimento é mais eficazmente obtido por delegação a agências nacionais ou supranacionais".

O que distingue o modelo de agências do modelo burocrático tradicional, então, é a combinação de conhecimentos e experiência específicos e independência juntamente com a especialização, numa gama bastante estreita, de questões de política. Pois bem, o contraste entre agências especializadas e burocracias generalistas tem uma analogia interessante com a maneira pela qual as legislaturas organizam seu trabalho através de comissões e subcomissões especializadas. O sistema de comissões mais antigo e mais plenamente desenvolvido é o do Congresso dos Estados Unidos. As comissões parlamentares têm jurisdição quase monopolítica sobre um pequeno conjunto de questões de política. Isto inclui o poder de fazer propostas, bem como poderes de veto sobre propostas feitas por legisladores que não façam parte da comissão relevante. Assim, as comissões permitem que seus membros tenham influência extraordinária sobre um subconjunto de políticas. As comissões parlamentares tendem a adotar um estilo de tomada de decisões não-partidário e aberto à solução de problemas, em vez do estilo tradicional da barganha que caracteriza as políticas distributivas (Krehbiel, 1992).

O sistema de comissões não está tão bem desenvolvido na maioria dos Parlamentos europeus, mas a situação está se modificando rapidamente. Assim, embora as comissões seletas do Parlamento britânico costumassem ser obscuras e bastante inócuas (Craig, 1994), recentemente a revista The Economist pôde escrever sobre uma revolução silenciosa que está transformando o Parlamento: "Seu verdadeiro trabalho já não se realiza no plenário da Câmara dos Comuns, onde o debate ... se limita ao bate-boca partidário ritual. A ação mudou-se para o andar de cima, para as comissões seletas compostas de todos os partidos, onde os parlamentares agora centram seus esforços no sentido de fazer responsabilizar o Poder Executivo" (12 março de 1994, p.47).

As similaridades estruturais entre o sistema de comissões e o modelo de agências explica realmente porque o controle político das agências reguladoras é exercido em grande medida através de comissões de supervisão. Uma explicação teórica poderia ser desenvolvida, como segue. A teoria do agente-principal prevê que, entre os responsáveis políticos das agências estatutárias, os legisladores seriam os mais influentes. Isto porque são os estatutos que criam as agências e proporcionam a estrutura de incentivos que deveria minimizar a 
divergência entre as intenções legislativas e os resultados em termos de regulação. A teoria também pressupõe, entretanto, que a informação é distribuída de maneira assimétrica. Os agentes normalmente têm mais informação do que seus superiores sobre os pormenores das tarefas a eles confiadas e sobre suas próprias preferências, capacidades e ações. Daí eles poderem aproveitar-se do alto custo da mensuração de suas características e de seus desempenhos para se dedicarem a comportamentos oportunistas.

Para reduzir esses custos das agências, os legisladores não apenas criam um sistema adequado de incentivos, mas também julgam ser de seu interesse criar mecanismos especiais para monitorar o comportamento de seus agentes. As comissões legislativas, que têm quase jurisdição monopolítica sobre um pequeno subconjunto de políticas, são esses instrumentos de monitoramento. O apoio empírico a esta conclusão é suprido por vários estudos norte-americanos. Assim, Weingast e Moran (1983) utilizaram dados anuais sobre decisões da Comissão Federal de Comércio (FTC) para mostrar que as preferências em matéria de políticas das comissões parlamentares, que têm responsabilidades de supervisão, desempenham um papel importante na determinação das ações da agência: mudanças nas preferências das comissões são o que provocam mudanças na política das agências. De modo semelhante, numa história pormenorizada, legislativa e jurídica, da elaboração de políticas anti-truste de 1969 a 1976, Kovacic (1987) sustenta que a FTC, em vez de ignorar as preferências parlamentares, conforme sugerem teorias mais antigas sobre os limites do controle político da burocracia, na realidade, escolheu programas que fossem consistentes com as preferências em matéria de políticas de sua comissão supervisora e a elas positivamente reativas. Um estudo muito pormenorizado de sete agências reguladoras, de fins dos anos 70 até a maior parte dos anos 80 , chegou a conclusões semelhantes (Wood e Waterman, 1991).

Como a regulação legal é uma prática muito mais recente na Europa, ainda não foram feitos estudos comparáveis das relações entre as agências e as comissões parlamentares, nem em nível nacional nem em nível comunitário. No entanto, as provas empíricas disponíveis parecem indicar que, também deste lado do Atlântico, as comissões parlamentares estão começando a desempenhar um papel importante na conformação das atividades das agências estabelecidas por lei, especialmente através do processo de nomeação e através da condução de audiências de supervisão. Por todas essas razões, no Quadro 1, as comissões parlamentares foram relacionadas entre as instituições características do Estado regulador, juntamente com as agências e os tribunais. 


\section{Novos atores, estilos diferentes de governança}

Além das novas estruturas organizacionais e dos novos arranjos institucionais, a mudança do Estado positivo para o Estado regulador acarreta o surgimento de novos atores na arena política, ou pelo menos uma redistribuição significativa do poder entre velhos atores. Por exemplo, tem sido sustentado que "o crescimento do Estado regulador transformou o único poder não eleito do estado, o Judiciário, de um árbitro relativamente neutro num protagonista ativo do jogo administrativo" (Seidman e Gilmour, 1986: 132).

Realmente, o envolvimento dos tribunais na administração e na formulação de políticas é talvez a consequiência mais importante do crescimento do Estado regulador. Quando a administração direta é substituída por relações contratuais com prestadores de serviços mais ou menos independentes, já não é mais possível resolver disputas através dos canais hierárquicos. $\mathrm{O}$ que costumava ser uma série de conflitos burocráticos internos passa a ser "externalizado", conduzindo ao litígio nos foros apropriados. No entanto, uma vez que os juízes aceitam a adequabilidade de seus tribunais como locais para a solução de disputas entre agentes normativos governamentais e agentes autônomos, eles se tornam atores significativos, às vezes os mais significativos, do processo administrativo (Ibidem, 136).

O papel dos juízes é igualmente essencial com relação à regulação e aos mercados. Aqui, novamente, a experiência norte-americana é muito instrutiva. Nos Estados Unidos, o processo de tomada de decisão das agências reguladoras foi em grande medida plasmado pelos tribunais. Desde a aprovação da Lei sobre Procedimentos Administrativos Federais (APA), em 1946, a tomada de decisões em matéria reguladora passou por um processo de judicialização de grande alcance. Nos termos da APA, as decisões das agências passaram a assemelhar-se em muito às decisões judiciais, inclusive devido à existência de um processo contencioso para a obtenção de provas a partir das partes contendoras, e da necessidade de um registro escrito para servir de base às decisões das agências. Essas exigências facilitaram muito o exame judicial das decisões administrativas. Por outro lado, as exigências da APA para fins de criação de normas eram menos estritas. Essas diferenças não influíram muito, à medida que muito da regulação era do tipo que estabelece taxas e atribui licenças e que, assim, dependia em grande medida de decisões. No entanto, quando a criação de regras (por exemplo, o estabelecimento de normas e padrões) tornou-se muito mais importante com o crescimento da regulação social nos anos 60 e 70, os tribunais prontamente começaram a desenvolver um grande corpo de novas regras de 
procedimento e de padrões e normas de exame judicial (Shapiro, 1988).

Em resumo, a política e as políticas de regulação nos Estados Unidos não podem ser entendidas sem se levar em conta o papel dos tribunais e, em especial, a possibilidade sempre presente do exame judicial das decisões das agências.

$\mathrm{Na}$ Europa, também, o crescimento da regulação está dando aos tribunais um novo papel no processo de elaboração de políticas. Isto é especialmente evidente em nível comunitário. Já no início dos anos 60, uma série de decisões marcantes da Corte Européia de Justiça (ECJ) conseguiu fazer passar o exame das leis dos Estados-membros da esfera do direito internacional para aquela do direito constitucional. Segundo a Corte, os tratados fundadores não são simplesmente acordos no âmbito do direito internacional, mas criam um regime constitucional. Daí, os próprios tratados, bem como leis comunitárias promulgadas sob o império dos mesmos, têm precedência sobre o direito internacional e têm efeitos diretos sobre os Estados-membros (Shapiro, 1992: 126).

Os poderes da ECJ, para exercer a revisão constitucional e administrativa sobre todas as leis comunitárias e sobre muitas leis dos Estados-membros, estão agora bem estabelecidos. Um determinado uso de tais poderes afetou profundamente a formulação de políticas em nível nacional e comunitário. Assim, a famosa decisão sobre o Cassis de Dijon, de 1979 - pela qual a ECJ determinou que os Estados-membros já não podiam evitar a promoção da comercialização dentro de suas fronteiras de um produto legalmente fabricado em outro Estado-membro - introduziu uma nova fase na formulação de políticas de regulação da $\mathrm{CE}$, caracterizada por uma ênfase reduzida na harmonização das regulações nacionais e por uma maior aderência ao princípio do reconhecimento mútuo.

Discutir este princípio vai além do propósito deste artigo, mas, a fim de dar uma idéia do impacto prático da decisão da Corte, pelo menos duas conseqüências deveriam ser mencionadas. Em primeiro lugar, o reconhecimento mútuo acarreta uma enorme expansão das regulações da CE, que agora incluem não apenas as decisões e estatutos aprovados pelo Conselho da $\mathrm{CE}$, mas também todas as medidas reguladoras adotadas pelos vários Estados-membros — no ponto em que essas medidas afetam a livre circulação de bens, serviços e pessoas no mercado europeu. Em segundo, o reconhecimento mútuo cria um sistema de concorrência entre as regulações dos Estados-membros. Desde o caso Cassis de Dijon, as regulações nacionais que satisfazem algumas exigências básicas comuns se aplicam a toda UE; portanto, os indivíduos e as atividades econômicas tenderão a se mudar para os países que ofereçam o ambiente regulador mais favorável. Isto é uma ilustração marcante do impacto de decisões judiciais sobre a formulação de políticas reguladoras na Europa. 
Os especialistas e os reguladores constituem outro grupo importante de atores. A regulação depende largamente do conhecimento científico de engenharia e de economia, que, conforme já observamos, sempre foi uma fonte de legitimidade das agências reguladoras serem o repositório de conhecimentos e experiências específicos. Tanto os defensores quanto os oponentes de medidas reguladoras específicas normalmente verbalizam seus argumentos na linguagem da "ciência da regulação", mais do que na linguagem mais tradicional do interesse ou da política classista. Paradoxalmente, o próprio fato de que a base científica é muitas vezes incerta e contestável tende a aumentar o papel dos especialistas em todos os estágios do processo regulatório.

Em parte, devido a essa dependência com relação aos conhecimentos e experiência específicos, os reguladores gozam de mais poder e discrição que outros administradores. Eles também fazem frente a uma estrutura diferente de incentivos profissionais e de carreira. Os chefes das agências reguladoras têm uma agenda bem definida, e seu sucesso é medido pela quantidade de itens da agenda que conseguem materializar. Centrar-se em objetivos reguladores específicos — seja fazendo aplicar-se leis sobre concorrência, melhorando a qualidade ambiental, seja protegendo os interesses econômicos ou de saúde dos consumidores - não apenas favorece um nível mais alto de profissionalização que é possível para generalistas burocráticos, mas também facilita a responsabilização pelos resultados — um ponto que retomaremos na seção seguinte.

Assim como as agências reguladoras centram sua atenção numa única tarefa, os novos grupos pluralistas que agem intensamente no Estado regulador se concentram cada um numa única questão - o meioambiente, a defesa do consumidor, direitos civis, questões de gênero. É instrutivo comparar-se esses grupos não-econômicos e preocupados com questões únicas com os grupos de interesse empresariais que até recentemente desempenhavam um papel tão importante na formulação de políticas macroeconômicas na Europa. Em países onde um único grupo de interesse podia falar em nome de seu setor na sociedade — associações patronais setoriais, sindicatos, grupos de ruralistas — monopólios foram criados ou fortemente incentivados pelo Estado. Os governos reforçaram o monopólio desses grupos empresariais porque necessitavam de sua cooperação para apoiar determinados tipos de políticas. A ajuda desses grupos era especialmente necessária para fins de planejamento econômico e de crescimento econômico liderado pelo governo, assim como para fins de formulação e implementação de políticas de renda e de bemestar social. Os países neocorporativistas, como a Suécia e a Áustria, por exemplo, dependiam, em grande medida, de associações patronais e de sindicatos para refrear o potencial inflacionário de seu comprometimento para com o pleno emprego (Wilson, 1990: 90). 
Por outro lado, num país como os Estados Unidos, onde o planejamento econômico, a política industrial e a política de renda nunca gozaram de amplo apoio político, e onde o poder político é fragmentado, nenhum grupo de interesse empresarial, com o direito de falar em nome de um setor econômico inteiro, poderia jamais existir: a cultura política dos Estados Unidos, o mais antigo dos Estados reguladores, é mais pluralista que corporativista. No entanto, embora os grupos de interesse empresariais tenham sido consideravelmente mais fracos nos Estados Unidos do que na Europa, os grupos não-econômicos defensores de questões únicas têm tido um impacto extraordinário sobre as políticas de regulação norteamericanas. Os tribunais foram muito importantes no processo de tornar possível essa influência - outra indicação da posição central que ocupa o Poder Judiciário no Estado regulador. Por exemplo, ao relaxar as exigências para o início de ação judicial nos anos 60 e 70, os tribunais norteamericanos tornaram mais fácil, para uma variedade de grupos de interesse público, o questionamento judicial de políticas, uma evolução especialmente importante na política de regulação (Ibidem: 89).

No entanto, o contraste entre a América pluralista e países europeus neocorporativistas não se aplica à Comunidade Européia. Conforme assinalam Streeck e Schmitter (1991), a negociação corporativista tripartite nunca realmente funcionou em Bruxelas, e, quando foi tentada, sempre foi tão marginal que não pôde chegar perto de um modelo neocorporativista de governança. No máximo, as relações entre o trabalho e o capital entram na arena política no nível da $\mathrm{CE}$, sob a forma de um conjunto de discretas questões de regulação social. Como tais, prestar-se-ão a ser tratadas por burocratas, peritos e especialistas e comissões intergovernamentais como o são, por exemplo, regras sobre etiquetagem relativas ao conteúdo de colesterol do óleo de palma ou regulamentos para a reciclagem de embalagens de água mineral. Mais que conduzir a negociação constitucional que fica por debaixo do sistema político, as questões tradicionais de classe da sociedade industrial terão de competir num plano igual com temas pósindustriais como a proteção ambiental, os direitos dos consumidores, a igualdade entre homens e mulheres, e assim por diante ... A alternativa ao neoliberalismo como modelo para a economia política européia, dentro desta evolução, claramente não é o neocorporativismo (alemão ou escandinavo). Parece ser mais provável que se adote um padrão de estilo norte-americano, de "pluralismo desunido" ou de "federalismo competitivo" organizado sobre não menos de três níveis: o das regiões, o dos Estadosnação e o de Bruxelas (Ibidem: 158-59).

Citei extensamente o perspicaz estudo de Streeck e Schmitter sobre a transição do corporativismo nacional para o pluralismo transnacional, a fim de mostrar como, partindo de um programa de pesquisa bastante 
diferente, eles chegam a conclusões muito semelhantes a respeito das conseqüências políticas da mudança para um modo regulador de governança. Essa mudança não apenas acarreta conseqüências políticas, jurídicas e institucionais discutidas até agora, mas também levanta importantes questões de ordem normativa.

\section{Novos padrões de legitimidade}

A democracia é comumente pensada como o governo da maioria. Uma formulação radical dessa visão sustenta que, numa democracia, as maiorias deveriam poder "controlar todo o governo" — o Legislativo, o Executivo e, se assim quisessem, também o Judiciário - e dessa forma controlar tudo o que se possa dizer a respeito da política. Nada esclarece mais o poder total da maioria que a sua capacidade de alterar e ajustar os padrões de legitimidade (Spitz, 1984, citado em Lijphart, 1991: 485). Uma interpretação tão radical do governo pela maioria também implica que o sistema de governo deveria ser unitário e centralizado, a fim de assegurar que não houvesse áreas de política que o Conselho de Ministros e sua maioria parlamentar deixassem de controlar.

Pois bem, o Estado regulador é caracterizado pelo pluralismo, pela difusão do poder e por extensa delegação de tarefas a instituições não-majoritárias, como as agências ou as comissões independentes. Se pressupomos que o único padrão da legitimidade democrática é a responsabilidade direta para com os eleitores ou para com o governo que expresse a maioria parlamentar do momento, então, um Estado de tribunais e de especialistas tecnocráticos obviamente estaria sofrendo de um déficit democrático. Em especial, as agências reguladoras independentes serão vistas como "anomalias constitucionais que não se inserem bem no quadro tradicional de controles, verificações e equilíbrios" (Veljanovski, 1991: 16), mesmo como desafios a princípios básicos da teoria democrática.

O modelo majoritário ou populista (Dahl, 1956), todavia, não é o único modelo possível. O modelo alternativo, ou de Madison, pretende compartilhar, dispersar, delegar e limitar o poder. O objetivo preponderante é proteger as minorias contra a "tirania da maioria", e as funções judicial, executiva e administrativa contra assembléias representativas e contra a opinião inconstante das massas (para declarações clássicas dessa posição, ver The Federalist, n. 48, 49 e 71). Assim, a delegação - uma estratégia não-majoritária cujo significado para o Estado regulador temos repetidamente acentuado - tenta restringir o governo da maioria, colocando a autoridade pública nas mãos de funcionários que tenham responsabilidade limitada ou indireta, seja para com as maiorias, seja para com as minorias. 
Segue-se que a legitimidade das agências independentes é muito menos problemática no contexto do modelo madisoniano de governança democrática. Realmente, não é difícil mostrar que, em termos de padrões de legitimidade derivada deste modelo, mais do que de princípios majoritários estritos, as agências independentes podem ser superiores a ministérios sob o controle direto de executivos políticos eleitos. Para isso, é conveniente distinguir-se entre uma dimensão procedimental e uma dimensão substantiva da legitimidade (Majone, 1996: 291-6).

A legitimidade procedimental implica, entre outras coisas, que as agências são criadas por estatutos democraticamente promulgados que definem a autoridade legal e os objetivos das agências; que os reguladores são nomeados por funcionários eleitos; que a tomada de decisões em matéria reguladora obedece a regras formais que muitas vezes exigem a participação pública; finalmente, que as decisões das agências devem ser justificadas e estão abertas ao escrutínio judicial. O meio mais simples e básico de melhorar a transparência e a responsabilização das agências é exigir que os reguladores forneçam razões para suas decisões. Isto porque uma exigência de fornecimento de razões ativa um número de outros mecanismos para controlar a discrição reguladora, tais como o exame judicial, a participação e a deliberação públicas, o exame pelos pares, a análise de políticas para justificar prioridades reguladoras, e assim por diante.

A já mencionada Lei Norte-Americana dos Procedimentos Administrativos (APA) dá uma excelente ilustração do potencial da exigência de fornecer razões. Será lembrado que a APA determina audiências quase-judiciais para decisão, mas é menos rigorosa quanto à formulação de regras. No último caso, não se exige que a agência baseie suas decisões exclusivamente nos comentários escritos submetidos por partes envolvidas, mas pode levar em consideração qualquer informação que julgue relevante no caso. No entanto, as regras devem ser acompanhadas de uma "declaração geral concisa de sua base e de sua finalidade", e não podem ser "arbitrárias, caprichosas, ou constituir abuso do poder discricionário".

Partindo de exigências tão gerais e aparentemente inócuas, os juízes federais têm conseguido formular novos princípios para melhorar a transparência e a racionalidade da formulação de regras. Por exemplo, eles exigiram que tanto os dados fatuais essenciais, em que se baseia uma regra, quanto a metodologia utilizada no raciocínio a partir dos dados até chegar-se à norma proposta, devem ser revelados para fins de comentários no momento em que a regra é proposta. Ademais, a discussão, por parte das agências, das bases e finalidades de suas regras, deve pormenorizar os passos do raciocínio da agência, enquanto que comentários significativos recebidos durante o período reservado aos comentários públicos devem ser 
respondidos no momento da promulgação final (Pedersen, 1975). Assim, hoje em dia, a formulação informal de regras tem de ser acompanhada de registros e conclusões ainda mais pormenorizadas e complexas do que fora inicialmente considerado para fins de decisões formais. Em grande medida, essas exigências procedimentais estritas foram conseguidas elaborando-se a exigência de fornecer razões contidas na APA (Shapiro, 1992 b: 185).

É duvidoso que muitos dos criadores do Tratado de Roma estivessem familiarizados com este estatuto, mas eles parecem ter entendido o significado da exigência de fornecer razões para melhorar a legitimidade das instituições não-majoritárias que estavam criando no nível europeu. Segundo o Artigo 190 do Tratado, "regulamentos, diretrizes e decisões do Conselho e da Comissão deverão declarar a razão em que se baseiam". O Artigo 15 do Tratado de Paris, que cria a Comunidade Européia do Carvão e do Aço, também determina que "decisões, recomendações e os pareceres da Alta Autoridade deverão declarar as razões em que se baseiam"; enquanto o Artigo $5^{\circ}$ do mesmo tratado afirma que "a Comunidade deverá ... publicar as razões para suas ações”. É interessante observar que não há qualquer exigência geral em se apresentar as razões que alicerçam as leis da maioria dos Estados-membros, de modo que estas disposições comunitárias eram, e em alguma medida ainda são, não apenas diferentes das leis nacionais, mas também mais avançadas do que essas (Hartley 1988). Esse exemplo mostra que instituições não-majoritárias podem estar sujeitas a normas e padrões de responsabilização mais estritos que os ministérios e departamentos tradicionais dos governos. Supõe-se que os últimos estejam sob o controle de ministros diretamente responsáveis perante o Parlamento; e embora esta forma de responsabilização seja amiúde um mito, ela proporciona uma desculpa para que não se imponham exigências formais de transparência e justificação racional sobre os departamentos centrais dos governos.

A legitimidade das instituições depende também de sua capacidade de gerar e manter a crença de que elas são as mais apropriadas para as funções a elas confiadas. No caso de instituições reguladoras independentes, os critérios relevantes da legitimidade substantiva são: consistência em matéria de políticas; os conhecimentos e experiência específicos e a habilidade de solucionar problemas dos reguladores; sua capacidade de proteger interesses difusos; o profissionalismo; e, o que é mais importante, uma definição clara dos objetivos da agência e dos limites dentro dos quais espera-se que esta opere.

Objetivos claros são importantes de um ponto de vista normativo, porque a responsabilização com relação aos resultados não pode ser posta em prática quando os objetivos são demasiado vagos ou demasiado amplos. A questão dos limites apropriados da responsabilidade das agências é mais delicada e necessita de exploração mais pormenorizada. Assevero 
que a distinção conhecida entre eficiência e redistribuição proporciona uma sólida base conceitual para decidir se a delegação da autoridade para formular políticas a uma entidade reguladora independente tem, pelo menos, uma legitimidade prima facie.

Numa democracia, as decisões públicas que dizem respeito à redistribuição de renda e de riqueza podem ser tomadas somente por meio de uma votação da maioria, uma vez que qualquer questão, a respeito da qual haja conflito inevitável, será derrotada diante da decisão majoritária. A redistribuição pura é um jogo de soma zero, uma vez que o ganho de um grupo na sociedade significa perda por parte de outro grupo. As questões de eficiência, por outro lado, podem ser consideradas jogos de soma positiva em que todos podem ganhar, desde que a solução certa seja descoberta. Portanto, essas questões poderiam ser resolvidas, em princípio, por unanimidade. O governo da unanimidade garante, em determinadas condições, que o resultado da escolha coletiva seja eficiente, no sentido usado por Pareto, uma vez que todos os adversamente afetados pela decisão coletiva podem vetá-la.

Naturalmente, a unanimidade é praticamente impossível numa grande polis, mas há alternativas que lhe seguem em excelência, das quais a delegação de tarefas de solução de problemas a uma agência especializada independente é a mais relevante no contexto atual. A tarefa mais importante que é delegada a agências reguladoras é a correção de falhas de mercado de modo a aumentar a eficiência das transações de mercado. É importante se observar que a adoção da eficiência como um padrão importante pelo qual os reguladores devem ser avaliados implica, inter alia, que os instrumentos reguladores não devem ser utilizados para finalidades redistributivas. As políticas reguladoras, como todas as políticas públicas, têm consequiências redistributivas, mas, para os reguladores, essas conseqüências deveriam representar limitações potenciais em matéria de política, mais do que objetivos de política. Somente um comprometimento para com a eficiência, para com um estilo de tomada de decisões voltado para a solução de problemas, mais que para a negociação, e para com a responsabilização por resultados, pode substantivamente legitimar a independência política dos reguladores. Da mesma forma, decisões que envolvam redistribuição significativa de recursos de um grupo social para outro não podem ser legitimamente tomadas por peritos ou especialistas independentes, mas somente por funcionários eleitos ou por administradores diretamente responsáveis ante funcionários eleitos. Isto é verdadeiro em nível nacional e, a fortiori, em nível europeu (Majone, 1996: 296-30).

Assim, a distinção entre políticas de aumento da eficiência de políticas redistributivas revela ser crucial para a legitimidade substantiva das políticas reguladoras. Repetindo, a delegação de importantes poderes de tomada de decisão a instituições independentes é democraticamente 
justificada somente na esfera das questões de eficiência, onde a dependência para com os conhecimentos e experiência específicos e para com um estilo de tomada de decisões voltado para a solução de problemas é mais importante que a dependência para com a responsabilização política direta. Quando prevalecem preocupações de natureza redistributiva, a legitimidade pode ser assegurada somente através de meios majoritários.

Em conclusão, o problema normativo chave do Estado regulador é como a independência e a responsabilização democrática das agências podem se tornar valores complementares que se reforçam um ao outro e não valores antitéticos. Tentei mostrar que a independência e a responsabilização podem ser conciliadas por meio de uma combinação de mecanismos de controle, mais que por meio de supervisão exercida a partir de qualquer ponto determinado do sistema político, quais sejam objetivos estatutários claros e limitados para proporcionar normas de desempenho que não sejam ambíguas; exigências de fornecer razões para decisões e exigências em termos de transparência para facilitar o exame judicial e a participação pública; disposições relativas ao processo legal para assegurar a justiça entre os inevitáveis ganhadores e perdedores de decisões reguladoras; profissionalismo para resistir à interferência externa e para reduzir o risco de um uso arbitrário da discrição de que dispõem as agências. Quando um sistema desses, de controles múltiplos, funciona como deve, ninguém controla uma agência; no entanto, a agência está "sob controle” (Moe, 1987).

\section{A comparação de estratégias e de estruturas}

Este artigo tentou proporcionar um esboço primário das conseqüências mais significativas, acarretadas por uma mudança de um modo de governança baseado na intervenção direta do Estado, apoiado pelo poder de tributar e de dispender para um modo de governança caracterizado pela elaboração de regras e por extensa delegação de poderes a instituições que operem com bastante autonomia em relação ao governo. A evidência e os argumentos apresentados anteriormente apóiam nossa hipótese inicial de que a tese de Chandler procede também no setor público. Conforme vimos, as mudanças estruturais induzidas pelas políticas estratégicas elaboradas por governos desde o fim dos anos 70 são muitas e têm longo alcance: novos atores e arranjos institucionais, novas áreas de conflito político, diferentes estilos de formulação de políticas, normas e padrões de legitimidade e métodos de responsabilização mais complexos.

Os limites de espaço não me permitiram fazer senão referências passageiras à pergunta de Chandler sobre as razões dos atrasos no desenvolvimento das estruturas necessárias para implementar as novas 
estratégias. Para lidar de maneira adequada com essa pergunta, seria necessário uma análise pormenorizada, país por país, ou mesmo investigações comparativas de setores industriais específicos, tais como o das telecomunicações. Mesmo sem o benefício de estudos dessa ordem, no entanto, é possível supor que o legado institucional e intelectual do Estado intervencionista é um impedimento de monta para o ajuste expedito das estruturas da governança às novas estratégias. Isto pode ser observado, por exemplo, na disseminada relutância em se aceitar todas as implicações da independência das agências.

Conforme sustentou-se na seção 6 , a delegação de poderes a uma agência politicamente independente é um meio importante pelo qual os governos podem comprometer-se com estratégias reguladoras que não teriam credibilidade na ausência dessa delegação. Vejamos: embora os governos europeus tenham consciência da importância da credibilidade das políticas num mundo crescentemente interdependente e estejam, portanto, preparados para aceitar a independência de reguladores nacionais e europeus, em princípio, na prática, eles são freqüentemente guiados por considerações de praticidade política no sentido de interferir nas decisões dos reguladores. Assim, a maneira pela qual as autoridades administrativas independentes francesas foram concebidas e seus poderes definidos, ainda há uma margem considerável de influência do governo central. Mesmo o relativamente poderoso Conselho da Concorrência não tem a autoridade para iniciar investigações. Esse poder permanece nas mãos do governo. Realmente, a Lei de Concorrência de 1986 não consegue levar sua própria lógica a uma conclusão final, mantendo uma margem considerável de arbítrio e discrição nas mãos do governo central e, em especial, reforçando o poder do ministro da Economia com relação a fusões (Demarigny, 1996).

Também, no Reino Unido, o legado do passado intervencionista é aparente na concepção das agências que foram criadas para regular os serviços públicos privatizados. Muitos poderes reguladores importantes foram dados diretamente ao governo em detrimento das novas agências, cujas operações dependem de todas as maneiras de decisões prévias do ministro quanto aos princípios a serem aplicados. O risco é de que tais poderes discricionários "poderiam ser objeto de abuso para exercer por detrás do pano pressões sobre os reguladores de maneira muito semelhante que prevalecia na época das indústrias nacionalizadas" (Prosser, 1989: 147). Na Grã-Bretanha, como alhures na Europa, ainda é uma questão aberta, como os limites da independência política dos reguladores serão definidos.

A questão permanece aberta também no nível da $\mathrm{CE}$, e isso é ainda mais preocupante, uma vez que a credibilidade e a coerência do direito regulador europeu dependem, de modo crucial, da percepção de que a Comissão seja capaz de estar desejosa de pôr em vigor as regras comuns de maneira objetiva e eqüitativa. Precisamente por esta razão, 
o artigo 157 do Tratado de Roma declara, em parte, que "os membros da Comissão deverão, no interesse geral da Comunidade, ser completamente independentes no cumprimento de seus deveres ... Eles não deverão buscar nem receber instruções de qualquer governo ou de qualquer outra entidade".

Na prática, todavia, os membros da Comissão não são imunes a influências políticas oriundas tanto dos Estados-membros quanto de dentro da própria Comissão. Embora não devam buscar atender aos interesses nacionais, muitos membros da Comissão Européia são políticos que, depois de deixar Bruxelas, retornarão a seus países de origem para lá continuarem suas carreiras. Isso cria enorme dificuldades para se resistir às pressões nacionais. Por outro lado, a Comissão é um corpo colegiado, e a necessidade de se chegar a uma maioria dentro do collegium em várias ocasiões tem produzido decisões reguladoras imperfeitas ou inconsistentes.

Essas preocupações se refletem nas propostas de transformar a Direção de Concorrência da Comissão, DG IV, numa autoridade européia de concorrência, independente não apenas com relação aos Estados-membros, mas também com relação à própria Comissão. Um modelo freqüentemente citado a esse respeito, e realmente uma das forças vetoras por detrás de tais propostas, é o Escritório Alemão de Cartéis. É verdade que o próprio Escritório de Cartéis não é completamente imune a influências políticas. No entanto, os procedimentos que o governo alemão deve seguir quando quer passar por cima de uma decisão do Escritório acarretam altos custos políticos e tornam a interferência claramente visível para todos. As relações entre a Comissão e o Escritório Europeu de Cartéis poderiam ser reguladas de maneira semelhante.

Também há propostas para um Escritório Europeu de Telecomunicações, enquanto uma Agência Européia de Avaliação de Medicamentos (EMEA) está operando desde fevereiro de 1995. No entanto, a EMEA não pode tomar decisões autônomas a respeito do licenciamento, em toda a Comunidade, de novas drogas medicinais, mas deve submeter suas recomendações à aprovação da Comissão. Isso ocorre porque a criação de agências reguladoras realmente independentes no nível europeu apresenta problemas jurídicos que somente uma revisão dos tratados poderia resolver de maneira satisfatória. Por outro lado, delegar poderes autônomos a essas agências seria um meio importante de adaptar o atual quadro institucional às realidades de uma UE expandida. Infelizmente, no momento em que escrevo este artigo, parece altamente improvável que a conferência intergovernamental em curso venha criar as necessárias bases legais.

A questão da independência das agências é somente um exemplo, embora especialmente revelador das dificuldades experimentadas tanto em nível nacional quanto europeu, para adaptar estruturas tradicionais a novas estratégias reguladoras. Seria pouco sábio pressupor-se 
que essas dificuldades possam ser vencidas num período curto de tempo como também esquecer que a concorrência internacional ocorre não apenas entre produtores de bens e serviços, mas, crescentemente, também entre regimes reguladores. A concorrência reguladora recompensará regimes nos quais as inovações institucionais não fiquem muito atrás das novas estratégias.

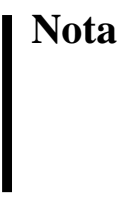

1 Texto publicado na Revista Journal of Public Policy, v. 17, Part 2 may-august 1997, p.139-167.

\section{Referências bibliográficas}

BALDwIn, Robert. (1996), Regulatory Legitimacy in the European Context: the British Health and Safety Executive, in Majone 1996, 83-105.

Chandler, Alfred D. Jr.. (1962), Strategu and Structure. Cambridge, MA.: MIT press.

Commission of the European Communities. (1985), Completing the Internal Market. Luxembourg: Office for Official Publications of the European Comunities.

ConseIl D'Etat. (1993), Rapport Publique 1992. Paris: La Documentation Française, Études et Documents.

CRAIG, P. P.. (1994), Administrative Law, terceira edição, Londres: Sweet \& Maxwell.

DAHL, Robert A.. (1956), A Preface to Democratic Theory. Chicago: The University of Chicago Press.

Demarigny, Fabrice. (1996), Independent Administrative Authorities in France and the Case of the French Council for Competition, in Majone 1996, 157-179.

De Muth, Christopher C.. (1984), “A Strtategy for Regulatory Reform”, Regulation 4: 25-30.

Dowding, Keith. (1995), The Civil Service, Londres: Routledge.

Dunleavy, Patrick. (1991), Democracy, Bureaucracy and Public Choice, Londres: HarvesterWheatsheaf.

FAInsod, Merle. (1940), Some Reflexions on the Nature of the Regulatory Process, in K. Friedrichs e P. Mason (editores), Public Policy, Cambridge, MA: Harvard University Press, 72-100.

Gatsios, Konstantine e Paul Seabright. (1989), "Regulation in the European Community”, Oxford Review of Economic Policy, 5: 2, 37-60.

HartLey, T. C.. (1988), The Foundations of European Community Law, Oxford: Clarendon Press. Hood, Christopher e James, Oliver. (1996), Regulation inside British Government: The Inner Face of the Regulatory State? , Londres: Department of Government, London School of Economics, Discussion Paper $n^{\circ} 1$. 
Hood, Christopher e Colin, Scott. (1996), Bureacratic Regulation and New Public Management in the UK. Mirror Image Developments?: Department of Government, London School of Economics, Discussion Paper $n^{\circ} 2$.

Kovacic, William E.. (1987), The Federal trade Commision and Congresional Oversight od Antitrust Enforcement: A Historical Perspective, in R. J. MacKay, J. C. Miller III, B. Yandel (editores) Public Choice and Regulation, Stanford, CA: Hoover Institution Press, 63-20.

KREHBIEL, Keith. (1992), Information and Legislative Organisation, An Arbor, MICH.: The University of Michigan Press.

Landis, James M.. (1966), The Administrative Process, New Haven CT.: Yale University Press [publicadooriginalmente em 1938].

LAUDATI, Laraine. (1996), The European Commission as Regulator: The Uncertain Pursuit of the Competitive Market, in Majone 1996, 29-261.

LIJPHART, Arend. (1991), "Majority Rule in Theory and Practice: The Tenacity of a Flawed Paradigm”. International Social Science Journal, 129/1991: 483-493.

Litan, Robert E. e William D. Nordhaus. (1983), Reforming Federal Regulation, New Haven, CT: Yale University Press.

Majone, Giandomenico. (editor) (1990), Deregulation or Re-regulation? Londres: Pinter. MAJone, Giandomenico. (1996), Regulating Europe, Londres: Routledge.

Moe, Terry. (1987), "Interests, Institutions and Positive Theory: The Politics of the NLRB'”. Studies in American Political Development 2: 236-299.

NisKanen, William A., Jr.. (1971), Bureaucracy and Rerepresentative Government, Chicago: Aldine-Atherton.

Pedersen, William F. Jr.. (1975), "Formal Records and Informal Rule-Making”, Yale Law Journal 85: 38-88.

Prosser, Tony. (1989), "Regulation of Privatised Enterprises: Institutions and Procedures", in Leigh Huncher e Michael Moran (editores) Capitalism, Culture and Economic Regulation, Oxford: Clarendon Press, 135-165.

Seidman, Harold e Gilmour, Robert . (1986), Politics, Position and Power, quarta edição. Nova York: Oxford University Press.

ShaPIRO, Martin. (1988), Who Guards the Guardians? Athens, GA.: The University of Georgia Press.

ShapIRo, Martin. (1992a), “The European Court of Justice”, in Alberta M. Sbragia (editora). Europolitics, Washington, DC.: The Brookigns Institution, 123-156.

SHAPIRO, Martin. (1992b), "The Given Reasons Requirement", Chicago: The University of Chicago Legal Forum, 180-220.

Sprtz, Elaine. (1984), Majority Rule, Chatham N.J.: Chatham House Publishers.

Stiglitz, Joseph E.. (1988), Economics of the Public Sector, Nova York: W. W. Norton.

Streeck, Wolfgang e Schmitter, Phillippe C.. (1991), "From National Corporatism to Transnational Pluralism: Organised Interests in the Single European Market. Politics and Society 19, 133-164.

Tsoukalies, Loukas. (1993), The New European Economy, Oxford: Oxford University Press.

VelJanovski, Cento. (1991), "The regulation Game”, in Cento Veljanovski (editor) Regulators and the Market, Londres: Institute of Economic Affairs, 3-28.

Veingast, Barry R. e Moran, Mark J.. (1983), "Bureaucratic Discretion or Congresional Control? Regulatory Policy Making in the Federal Trade Commision". Journal of Political Economy 91: 765-800.

WILson, Graham K.. (1990), “American Interest Groups in Comparative Perspective”, in Mark P. Petracca (editor): The Politics of Interest, Boulder, CO.: Westview Press, 80-95.

Wood, Dan B. e Waterman, Richard W.. (1991), "The Dynamics of Political Control of the Bureaucracy”. American Political Science Review. 85: 801-828. 


\section{Do Estado positivo ao Estado regulador: causas e conseqüências de mudanças no modo de governança \\ Giandomenico Majone}

Desde o fim dos anos 70, os governos europeus têm sido forçados a mudar seus modos tradicionais de governança como reação a tendências, tais como a crescente concorrência internacional e a integração econômica e monetária cada vez mais profunda no âmbito da União Européia. A adaptação estratégica às novas realidades resultou num papel reduzido para o Estado positivo, intervencionista, e no crescimento correspondente do papel do Estado regulador: a criação de regras está substituindo a tributação e a despesa por parte do Estado. A primeira parte do artigo identifica três conjuntos de estratégias conducentes ao crescimento do Estado regulador, como regulador externo ou de mercado e como regulador interno da administração descentralizada. A segunda parte examina mudanças estruturais importantes, induzidas por mudanças nas estratégias reguladoras.

\section{Del Estado positivo hacia el Estado regulador: causas y consecuencias de cambios en la gobernabilidad \\ Giandomenico Majone}

Desde fines de los años setenta, los gobiernos europeos han sido forzados a cambiar sus modos tradicionales de gobernabilidad, como una reacción a tendencias como la creciente competencia internacional y la integración económica y monetaria cada vez más profunda en el ámbito de la Unión Europea. La adaptación estratégica a las nuevas realidades ha tenido como resultado un papel reducido para el Estado positivo, intervencionista, y en el crecimiento correspondiente del papel del Estado regulador; la creación de reglas está sustituyendo a la tributación y a los gastos por parte del Estado. La primera parte del artículo identifica tres conjuntos de estrategias que conducen al crecimiento del Estado regulador, como regulador externo o de mercado, y como regulador interno de la administración descentralizada. La segunda parte examina cambios estructurales importantes que se han producido mediante cambios en las estrategias de regulación.

\section{From the positive State to the regulatory State: causes and consequences for changes in the mode of governance}

\section{Giandomenico Majone}

Since the late 1970's, European governments have been forced to change their traditional modes of governance, as a reaction to trends such as the growing international competition and the ever deepening economic and monetary integration within the European Union. The strategic adaptation to the new realities brought about a reduced role for the positive, interventionist State and in the corresponding growth of the role of the regulatory State: the creation of rules is by way of replacing taxation and expenditure by the State. The first part of the article identifies three sets of strategies leading to the growth of the regulatory State, as an external or market regulator, and as an internal regulator of a decentralised administration. The second part reviews important structural changes produced by changes in the regulatory strategies.
Revista do

Serviço

Público

Ano 50

Número 1

Jan-Mar 1999

Professor

visitante de Ciências Políticas

no Instituto

Universitário

Europeu, em

Florença, Itália 